Portland State University

PDXScholar

Environmental Science and Management

Faculty Publications and Presentations

\title{
Hydrochorous Seed Dispersal in Riparian Forests Altered by Urbanization
}

Christa von Behren

Portland State University, christa.vonbehren@gmail.com

J. Alan Yeakley

University of Maryland - Baltimore

Follow this and additional works at: https://pdxscholar.library.pdx.edu/esm_fac

Part of the Forest Biology Commons

Let us know how access to this document benefits you.

Citation Details

von Behren, C., \& Yeakley, J. A. (2020). Hydrochorous seed dispersal in riparian forests altered by urbanization. Ecosphere, 11(2), e03049.

This Article is brought to you for free and open access. It has been accepted for inclusion in Environmental Science and Management Faculty Publications and Presentations by an authorized administrator of PDXScholar. Please contact us if we can make this document more accessible: pdxscholar@pdx.edu. 


\title{
Hydrochorous seed dispersal in riparian forests altered by urbanization
}

\author{
Christa VON BeHRen ${ }^{1} \uparrow$ AND J. Alan YeAKLeY ${ }^{2}$ \\ ${ }^{1}$ Department of Environmental Science and Management, Portland State University, P.O. Box 751, Portland, Oregon 97207 USA \\ ${ }^{2}$ Department of Geography and Environmental Systems, University of Maryland, Baltimore County, 1000 Hilltop Circle, Baltimore, \\ Maryland 21250 USA
}

Citation: von Behren, C., and J. A. Yeakley. 2020. Hydrochorous seed dispersal in riparian forests altered by urbanization. Ecosphere 11(2):e03049. 10.1002/ecs2.3049

\begin{abstract}
While riparian habitat alterations from urban stream syndrome are known to affect vegetation establishment and survival, the degree to which riparian seed delivery by hydrochory is affected by urbanization is unclear. We hypothesized that (1) there would be a reduction in the overall number of seeds deposited by streams as watershed urbanization increased; and (2) in the most urbanized watersheds, seeds deposited by water would be predominantly from species with traits favoring dispersal in general, including tall stature and high seed production, and favoring deposition by water in particular, including large seed size and the presence of a dispersal appendage. Nine riparian forests, selected using a stratified random approach, were studied along a gradient of watershed impervious surface area (1-41\%) in the Portland, Oregon, USA, metropolitan region. Seeds deposited by water were collected using turf traps four times over a 15-month period that spanned both wet and dry seasonal conditions. Along the urbanization gradient of increasing total impervious area, there was a significant decrease in the total number of seeds deposited by hydrochory (adjusted $R^{2}=0.74 ; P<0.01$ ). Deposition of seeds from shade-tolerant and native taxa by water decreased as surrounding urbanization increased (adjusted $R^{2}=0.57 ; P<0.05$ ). Deposition of non-native seeds increased as urban development within $500 \mathrm{~m}$ from the riparian area increased (adjusted $R^{2}=0.79, P<0.01$ ). The findings demonstrate that seed dispersal patterns in riparian areas are altered by urbanization. During higher rainfall seasons, flashy hydrology and stream bank scour appear to alter seed delivery in highly urban watersheds. While the urban stream syndrome contributes to altered dispersal, other urbanization pressures that affect source populations, such as vegetation removal, also limit seed delivery to riparian sites. Overall, our results suggest that urbanization can limit the regeneration processes that maintain vegetation communities in riparian forests.
\end{abstract}

Key words: plant ecology; riparian ecology; riparian vegetation; seed source populations; seed traps; stream bank scour; urban hydrology; urban stream syndrome.

Received 4 September 2019; revised 2 December 2019; accepted 9 December 2019; final version received 19 January 2020. Corresponding Editor: Debra P. C. Peters.

Copyright: (c) 2020 The Authors. This is an open access article under the terms of the Creative Commons Attribution License, which permits use, distribution and reproduction in any medium, provided the original work is properly cited.

$\dagger$ E-mail: christav@pdx.edu

\section{INTRODUCTION}

Many local and landscape-level variables are known to be correlated with urban riparian vegetation composition (Metzger 2000, von Behren et al. 2013); however, the mechanisms through which these variables act to affect vegetation in urban riparian areas are not entirely clear. Recent studies suggest that urban land use alters dispersal processes, contributing to altered urban vegetation patterns. Forest fragmentation has been found to lead to dispersal limitation of forest species (Ehrlen and Erikkson 2000, Honnay et al. 2002, McEuen and Curran 2004) and to alter 
dispersal patterns for animal-dispersed species (Alados et al. 2010). It is less clear how hydrochory (water dispersal) is affected by surrounding urbanization.

In riparian areas, hydrochory can be a major factor shaping vegetation communities (Merritt et al. 2010, Moggridge and Gurnell 2010, Nilsson et al. 2010, Fraaije et al. 2015). Hydrochory can connect otherwise fragmented habitats by depositing seeds in sites that could not be reached by wind or animal dispersal alone (Vogt et al. 2004, Hérault and Honnay 2005, Merritt et al. 2010). In urban areas with heavily altered streams, however, the role of hydrochory is unclear. Streams in urbanizing regions frequently display signs of urban stream syndrome, including higher peak flows, incised channels, and stream bank scour (Groffman et al. 2003, Walsh et al. 2005, Yeakley 2014).

It also is unclear whether, and to what extent, dispersal of species with varying life-history traits and seed morphologies may be differentially affected by watershed urbanization. Species with tall mature height and high seed production rates are more likely to have seeds reach streams for further transport than those lacking these features (Willson and Travaset 2000, Boedeltje et al. 2003). Seeds that have dispersal appendages, such as wings or hooks, often have enhanced floating ability, as well as an increased likelihood of catching on leaves, twigs, or other objects along stream banks (Goodson et al. 2003, Chambert and James 2009). Large seed size can also facilitate deposition (Samuel and Kowarik 2013). In the challenging depositional environments of urban stream banks, these features may make seed dispersal and deposition more likely.

To date, most studies of hydrochory have involved heavy monitoring on two to three streams to evaluate seasonal deposition patterns and relationships with stream hydrology (Merritt and Wohl 2002, Fraaije et al. 2017), or releasing seeds or artificial seeds to investigate relationships between seed traits and travel and deposition patterns (Engstrom et al. 2009, Cunnings et al. 2015). Few studies have evaluated hydrochory on a larger number of streams across a broad urban region or have examined relationships with landscape-level features. The goal of this study was to determine how seed deposition patterns by hydrochory change with increasing levels of urban development throughout a watershed. We hypothesized that (1) there would be a reduction in the overall number of seeds deposited by water as watershed urbanization increased; and (2) in the most urbanized watersheds, seeds deposited by water would be predominantly from species with traits favoring dispersal in general, including tall stature and high seed production rate, and favoring deposition by water in particular, including large seed size and the presence of structure or appendage to facilitate water dispersal.

\section{Methods}

\section{Site selection}

Nine forested riparian areas were selected in the Portland, Oregon metropolitan area $\left(45.5^{\circ} \mathrm{N}\right.$, $\left.122.6^{\circ} \mathrm{W}\right)$, along a gradient of watershed total impervious surface area (TIA; e.g., Morse et al. 2003, Chadwick et al. 2006) using a stratified random approach. Eligible sites had permanent second- to fourth-order streams, had at least 1 ha of forested area, and had $100 \mathrm{~m}$ of accessible stream bank. We used data from the USGS National Hydrography Dataset (https://www.usgs.gov/c ore-science-systems/ngp/national-hydrography) to select all permanent second- through fourthorder streams within $5 \mathrm{~km}$ of the Portland metro area urban growth boundary. Stream order was manually delineated in ArcGIS version 10.4 (ESRI 2014). Land cover data from the 2011 National Land Cover Database (NLCD; Homer et al. 2015) were used to identify riparian sites along these streams with at least 1 ha forest cover. From these sites, watersheds were delineated using the USGS Streamstats tool (https:// streamstats.usgs.gov). Watershed TIA was calculated by clipping the NLCD impervious surface area raster layer to delineated watersheds, and potential sites were assigned the following TIA categories: $0-5 \%, 5-15 \%, 15-30 \%$, and $>30 \%$. These categories were established based on evidence of thresholds of impact at different levels of TIA (May and Horner 2000, Booth et al. 2002, Randhir and Ekness 2009). Two sites were selected in each category, using random selection for TIA categories with more than two possible sites, giving eight study sites. One additional site with $>15 \%$ TIA (either $15-30 \%$ or $>30 \%$ ) and one 
with $<15 \%$ TIA (either $0-5 \%$ or $5-15 \%$ ) were randomly selected from the remaining viable sites. Permission to access sites was obtained from all landowners. Study sites were established in December 2014. Of the 10 selected sites, one was lost to beaver activity and another to vandalism, leaving eight sites. One site was replaced in March 2015, giving a total of nine sites (Table 1, Fig. 1).

\section{Field methods}

Turf mats with 3.81-cm artificial grass blades were used to sample seeds deposited by streams (Wolters et al. 2004). Six pairs of $20 \times 20 \mathrm{~cm}$ turf mats were fixed to the stream bank at each site. Six stream bank surfaces with slope $<30^{\circ}$ were randomly selected along a 100-m stream transect. At each sample location, mats were placed at two elevations; the upper mat was located just below the high-water mark, with the lower mat closer to the stream, up to a $50 \mathrm{~cm}$ distance along the bank from the upper mat. Stream bank topography varied across depositional sites, and as a result, the distances between the traps in each pair also varied, ranging from 5 to $50 \mathrm{~cm}$. The vertical distance between the water surface and the lower edge of each trap was measured in the summer and winter. Seed traps were collected at the end of each of four collection periods: December 2014-mid-March 2015 (Win1), mid-March-July 2015 (Spr), July-November 2015 (Sum/Fa), and November 2015-March 2016 (Win2).
To measure stream water level, one Onset HOBO water-level data logger (Onset Computer Corporation, Bourne, Massachusetts, USA) was installed in each stream. The logger was placed in the location where it could best be secured, and position along the $100-\mathrm{m}$ transect varied by site. A $t$-post was pounded into the stream bed $\sim 0.5 \mathrm{~m}$ deep and a $1 \mathrm{~m}$ long PVC tube attached to the t-post with hose clamps. The data logger was attached with waterproof tape to an aluminum rod, which fit snuggly inside the PVC tube. The logger was positioned at the bottom of the PVC tube, at the level of the stream bed. Loggers recorded pressure every $15 \mathrm{~min}$. Daily atmospheric pressure data measured at the Portland International Airport from the National Climatic Data Center (https://www.ncdc.noaa.gov) were used to convert data logger pressure measurements to water depth.

Vegetation was surveyed in all sites during the summer of 2016. The line-intercept method was used to map trees (woody vegetation taller than $1.5 \mathrm{~m}$ ) to the nearest decimeter along three transects extending perpendicularly from the stream bank $60 \mathrm{~m}$, or to the edge of the forest patch (minimum $15 \mathrm{~m}$ ). Vegetation transects were located at 25,50, and $75 \mathrm{~m}$ along the stream transect. Percent cover of herbs and shrubs (woody plants shorter than $1.5 \mathrm{~m}$ ) was estimated in one $1-\mathrm{m}^{2}$ quadrat centered on each of the 12 seed traps. Vegetation was identified to the species level using Hitchcock and Cronquist (1973) and Meyers et al. (2015).

Table 1. Watershed characteristics of nine study sites.

\begin{tabular}{|c|c|c|c|c|c|}
\hline Site Name & Site Owner & Stream & $\begin{array}{l}\text { Watershed } \\
\text { area }(\mathrm{Ha})\end{array}$ & $\begin{array}{l}\text { Watershed } \\
\text { TIA (\%) }\end{array}$ & $\begin{array}{l}\text { Watershed forest } \\
\text { cover }(\%)\end{array}$ \\
\hline East Bliss Butte (EBB) & Metro & Kelley Creek & 172.0 & 1 & 62 \\
\hline Dabney State Recreation Area & Oregon State Parks & Bonnie Brook & 132.6 & 2 & 33 \\
\hline Clackamas & $\begin{array}{c}\text { Clackamas County Water } \\
\text { Environment Services }\end{array}$ & Rock Creek & 1690.7 & 8 & 29 \\
\hline Pecan Creek & Metro & Pecan Creek & 154.8 & 12 & 20 \\
\hline Wilson Creek & Metro & Wilson Creek & 490.0 & 13 & 28 \\
\hline Butler Creek Trail & City of Gresham & Butler Creek & 320.9 & 24 & 35 \\
\hline Jordan Woods & $\begin{array}{c}\text { Tualatin Hills Parks and } \\
\text { Recreation }\end{array}$ & Cedar Creek & 576.3 & 28 & 17 \\
\hline Metzger Park & City of Tigard & Ash Creek & 774.8 & 34 & 8 \\
\hline Foley-Balmer Natural Area (FB) & $\begin{array}{l}\text { Portland Parks and } \\
\text { Recreation }\end{array}$ & Tryon Creek & 372.8 & 41 & 6 \\
\hline
\end{tabular}

Notes: The study sites were located on nine different streams with 6 different landowners, all public agencies. The watersheds of study sites ranged from 154.8 ha to 1690.5 ha in size. Watershed TIA (total impervious surface area) ranged from $1 \%$ to $41 \%$, and watershed forest cover ranged from $6 \%$ to $62 \%$. There was a significant, negative relationship between watershed TIA and watershed forest cover (adjusted $R^{2}=0.56 ; P<0.05$ ). 


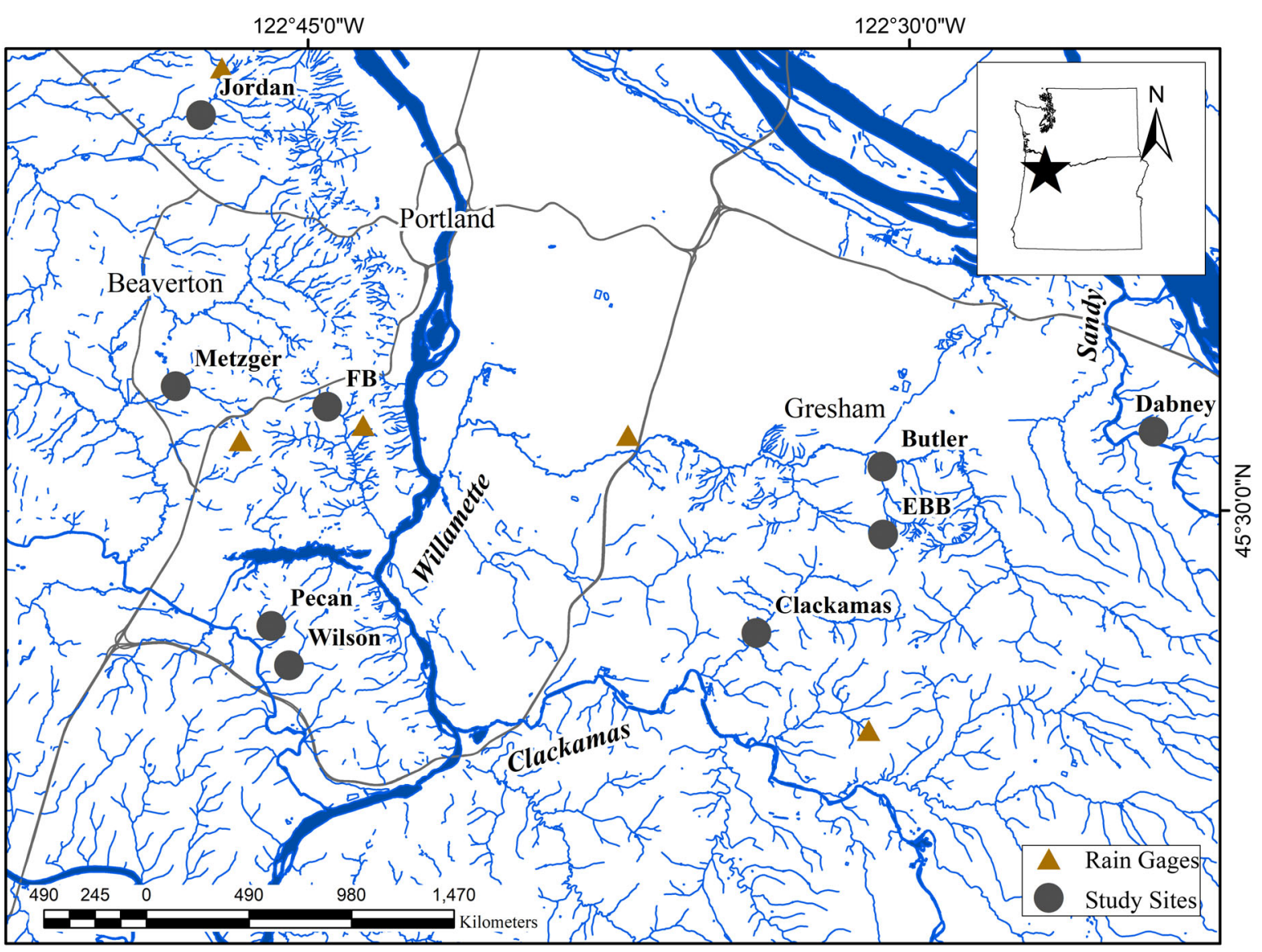

Fig. 1. Nine study sites in the Portland, Oregon metropolitan area. The nine study sites ranged from $1 \%$ to 41\% watershed TIA. Data from five HYDRA rain gages (https://www.or.water.usgs.gov/non-usgs/bes) were used to characterize rainfall across the region.

\section{Laboratory methods}

The seed extraction method was used for seed identification as it has been found to allow for the identification of a wide range of forest taxa (Brown 1992). Turf traps were rinsed in tubs of water to remove seeds and sediment. This material was poured through two sieves: a 2-mm mesh sieve stacked on top of a $0.125-\mathrm{mm}$ mesh sieve. Material trapped in the 2-mm mesh sieve was mostly organic and was kept for analysis. For material caught in the $0.125-\mathrm{mm}$ sieve, a chemical extraction method was used to separate seeds and other organic matter from inorganic particles (Malone 1967). To disaggregate the sample, it was divided into approximately 100 -g batches of sample material; each of these was added to a solution of $200 \mathrm{~mL}$ water, $40 \mathrm{~g}$ sodium hexametaphosphate,
$20 \mathrm{~g}$ magnesium sulfate, and $100 \mathrm{~g}$ sodium bicarbonate. The material was thoroughly stirred into the solution and left to rest for several minutes, allowing organic matter to float to the surface. This organic material was decanted into a 0.125$\mathrm{mm}$ mesh sieve. Each batch of sample material was mixed in solution and decanted three times. Extracted material was placed in a drying oven at $65^{\circ} \mathrm{C}$ and left until thoroughly dry. The material was then examined under a dissecting microscope, and all complete, unbroken seeds were identified and counted. Seeds were identified to species level when possible by comparison with a reference seed collection and with images from Cappers et al. (2006), the USDA PLANTS Database (https://plants.usda.cov), Bonner et al. (2008), and Wilson et al. (2014). 


\section{Analysis}

Landscape metrics were calculated for each site at three scales using ArcGIS. Buffer circles of 250 and $500 \mathrm{~m}$ were clipped to delineated watershed boundaries, giving 250- and 500-m cones upstream of each site (Sonoda et al. 2001). Cover of all NLCD categories was calculated in these cones, as well as in the entire watershed of each site. Rainfall data from the City of Portland Bureau of Environmental Services HYDRA network (https://or.water.usgs.gov/non-usgs/bes) were analyzed to verify that rainfall was similar across study sites. The nearest gage to each site was identified (Fig. 1), and mean daily rainfall across gages was calculated, as well as the percent difference from the daily mean for each gage.

We used water-level data to construct a flashiness index based on high pulse count (Wenger et al. 2010). For each collection period, the number of high pulse occurrences, defined as a series of water-level readings greater than twice the mean water level for the collection period, was tabulated for each stream. Additionally, the hydrographs for streams were visually compared for each collection period. Streams with higher numbers of high pulse counts, as well as taller, more narrow peaks in hydrographs, were considered flashier streams.

Taxa collected in seed traps were placed into trait classes related to seed dispersal and deposition (Appendix S1: Table S1; e.g., Hérault and Honnay 2005, Fraaije et al. 2017). For traits with continuous variables (seed weight and length, plant height, seed output), four to five classes were created based on natural breaks in the data, as well as metrics reported in the literature to be ecologically meaningful. Three traits were hypothesized to interact with streamflow and affect deposition by hydrochory: seed weight, seed length, and presence of a dispersal appendage. For taxa identified only to genus, mean values of seed weight and length for species present in the region (based on Christy et al. 2009) were calculated. Dispersal appendages included hairs, beaks, hooks, wings, or other structures that may facilitate water dispersal. Only structures attached to the unit dispersed by water were included; fleshy fruits were not included, as it was assumed that most seeds reach streams after passing through animal guts (Hampe 2004).
Additional traits were not expected to interact with streamflow patterns to result in seed sorting but were expected to affect the likelihood of seeds reaching a stream for secondary transport: growth habit, primary dispersal vector, maximum plant height, and seed output. Three additional traits, species origin, shade tolerance, and wetland indicator status, were not expected to relate to dispersal, but rather to surrounding development and forest cover.

We created an additional dataset including only taxa that represented potentially new species introductions to a trap microsite (Moggridge et al. 2009). For each seed trap pair, we defined potentially new herbaceous and shrub taxa as those found in seed traps but not in the standing vegetation in the $1-\mathrm{m}^{2}$ plots surrounding either trap in the pair, to eliminate seeds that may have fallen from directly overhanging vegetation. Because of the much larger expanse of tree crowns compared to herbs or shrubs, new tree taxa were defined as those found in seed traps, but not identified in any vegetation transects in the site. The resulting dataset (New dataset) was analyzed in parallel with the dataset containing all seeds (All dataset).

Generalized linear mixed models were used to explore effects of trap position (upper or lower) and collection period on number of seeds found in traps (Bolker et al. 2008, Fraaije et al. 2017). The function glmer in the R package lme4 (Bates et al. 2015) was used to run models using the Gauss-Hermite quadrature approach with a negative binomial distribution. Trap position, collection period, and the interaction between them were initially included as independent variables, with site treated as a random effect. Forward selection was used to select final variables, using Akaike's information criterion (AIC) evaluate model fit. Model variables were retained if their addition resulted in a decrease in AIC of at least 2. For nested models within 2 AIC, the simpler model was retained. Wald $F$ tests were used to test the null hypotheses of no model effect. Linear mixed-effects models were used to evaluate the relationship between vertical trap-to-water distance and number of seeds in traps. The $\mathrm{R}$ function lmer was used, with vertical distance as the fixed effect and site as a random effect.

We used linear regression to analyze deposition patterns along the TIA gradient. To evaluate 
deposition throughout the whole study, cumulative mean seed density was calculated for the eight sites with data across this period (all but the Dabney site; Fig. 1). For each site, the mean seed density (seeds per trap, $n=12$ ) for each collection period was calculated, and then, the means for all four collection periods were summed. Differences across the gradient in deposition of seeds in different trait classes were also examined.

We used nonmetric multidimensional scaling (NMDS) based on rank similarity of sites using the Bray-Curtis index to explore relationships between landscape variables in upstream cones and assemblages of seeds deposited in turf traps. Nonmetric multidimensional scaling was chosen because of its compatibility and robustness with species data (Kenkel and Orlóci 1986, Minchin 1987). The function envfit in the $R$ package vegan (Oksanen et al. 2012) was used to map landscape variables as vectors onto the ordination. Landscape variables with a significant association with the ordination $(P<0.05)$ were selected for further investigation of their relationships with seed deposition patterns. Ordinations were constructed based on cumulative mean seed deposition in each site from Win1 through Win2, using both All and New seed datasets. All statistical analyses were conducted in $R$ version 3.4.2 ( $R$ Development Core Team 2017).

\section{RESULTS}

\section{Land use composition}

Watersheds ranged from $1 \%$ to $41 \%$ TIA (Table 1) and from 5\% to $94 \%$ total development cover (sum of cover by the four NLCD development types). Total watershed forest cover ranged from $6 \%$ to $62 \%$. There was a significant, negative relationship between TIA and forest cover at the watershed scale (adjusted $R^{2}=0.56$; $P<0.05)$. Within a 500-m cone upstream from each site, total development cover ranged from $2 \%$ to $99 \%$, and forest cover from $0 \%$ to $78 \%$. Within a 250-m cone, development ranged from $0 \%$ to $100 \%$, and forest cover from $0 \%$ to $86 \%$. There was a significant, negative relationship between total development cover and forest cover at both the 500-m scale (adjusted $R^{2}=0.71$; $P<0.01$ ) and the 250-m scale (adjusted $\left.R^{2}=0.79 ; P<0.01\right)$.

ECOSPHERE *www.esajournals.org

\section{Rainfall and stream hydrology}

Five HYDRA rain gages were found to represent rainfall across the study region (Fig. 1). A mean of $168 \mathrm{~cm}$ of rain fell across the entire study area over the study period, with a mean of $44.5 \mathrm{~cm}$ in Win1 (December 2014-March 2015), $15.6 \mathrm{~cm}$ in Spr (March-July 2015), $16.7 \mathrm{~cm}$ in Sum/Fa (July-November 2015), and $91.2 \mathrm{~cm}$ in Win2 (November 2015-March 2016). The daily rainfall means at each of the gages were within $20 \%$ of the overall daily mean. Four of the five gages were within $10 \%$ of the overall daily mean.

We found a general relationship between watershed TIA and stream flashiness. Hydrographs showed an evident increase in stream flashiness as watershed TIA increased (Appendix S2: Fig. S1, S2, S3, and S4). The number of high pulse events per collection period generally increased with increasing watershed TIA, but there were some exceptions and variations across collection periods. Foley-Balmer, the highest TIA site $(41 \%)$, only had the highest number of high pulse events during one collection period, Win1 (December 2014-March 2015), and moderate hydrograph peaks (Appendix S2: Fig. S1). Hydrology, based on hydrograph patterns and high pulse count, was flashier at Butler $(24 \%$ TIA) and Metzger (34\% TIA), sites that had lower watershed TIA than Foley-Balmer, but that had higher development within a 250-m cone.

\section{Standing vegetation}

All study sites had mixed conifer and hardwood canopy. Across sites, 113 species were identified in the standing vegetation. More than $95 \%$ of transect length was covered by tree canopy in all sites. Shrub cover around seed traps ranged from $22 \%$ to $73 \%$, with Rubus spp. cover ranging from $2 \%$ to $30 \%$ (including $R$. spectabilis, $R$. bifrons, and $R$. parviflora). Understory cover ranged from $17 \%$ to $42 \%$. Sites varied in richness and Shannon diversity in the understory, shrub, and canopy layers, but all had the highest richness in the understory, and eight sites had the lowest richness in the shrub layer.

\section{Seed deposition patterns}

Seed traps were occasionally lost due to vandalism, animal damage, or large storms. Trap recovery rate averaged $87 \%$ across sites and 
collection periods. A total of 11,250 seeds were found across the study, representing 67 taxa. Potentially, new seeds accounted for $38 \%$ $(n=4267)$ caught in traps. Thirteen taxa made up $98 \%$ of seeds caught, with seeds that could not be identified making up 1\% (Table 2). Rubus spp. was the taxon most represented, accounting for $42 \%(n=4727)$ of seeds caught. Rubus spp. was found in both turf traps and the standing vegetation at all sites. The species of Rubus could not be determined from seed, but much of the seed was likely Rubus spectabilis (salmonberry), as this species was present in all sites in the standing vegetation. Rubus spp. was present as a potentially new taxon to the microsite at five study sites. There was no relationship found between Rubus spp. seed density in turf traps and Rubus spp. cover in the standing vegetation in trap microsites. Alnus rubra (red alder) accounted for $18 \%(n=2060)$ of seeds caught.

Generalized linear mixed model results showed that for both All and New seeds, collection period was a significant predictor of total number of seeds caught in traps, with significantly fewer seeds deposited in Sum/Fa than in Win1 $(P<0.001)$. Inclusion of trap position on the stream bank did not significantly improve model fit (Appendix S3: Table S1). Linear mixed model results showed no significant relationship between vertical water-to-trap distance, measured in either summer or winter, and total number of seeds caught in any collection period (Appendix S3: Table S2).

\section{Seed collection patterns across the TIA gradient}

Across the entire study period, there was a significant negative relationship between watershed TIA and cumulative mean seed density in traps $\left(y=-2.87+191.95 ; \quad\right.$ adjusted $\quad R^{2}=0.74 ;$ $P<0.01$; Fig. 2). During Win1, Spr, and Win2, there was a negative relationship between TIA and mean seed density (Fig. 3), though Win2 was the only individual period when this relationship was significant $(y=-1.28 x+70.11$; adjusted $\left.R^{2}=0.42 ; P<0.05\right)$. In Win1, there appeared to be higher seed density in sites below $15 \%$ TIA than sites above $15 \%$ TIA (Fig. 3), but results of a Wilcoxon rank-sum test were inconclusive $(0.05<P<0.1)$. In $\mathrm{Sum} / \mathrm{Fa}$, the period with the fewest total seeds collected at seven of the sites, there was a significant positive relationship between TIA and total seeds collected $\left(y=0.21 x+9.57 ;\right.$ adjusted $R^{2}=0.39 ; P<0.05$; Fig. 3). For New seeds, there was no detectable relationship between TIA and total seed deposition in any individual period, or cumulatively across the study.

The deposition pattern of All Rubus spp. seeds mirrored that of total seed deposition. In Win2, there was a significant, negative relationship between TIA and Rubus spp. density $\left(y=6.83 x-0.11\right.$; adjusted $\left.R^{2}=0.60 ; P<0.01\right)$, after square-root transformation. During Win1, a Wilcoxon rank-sum test showed that there were significantly more Rubus spp. seeds in the four low TIA sites than the four high TIA sites $(P<0.05)$. For New seeds, there were no

Table 2. Top taxa found in turf traps.

\begin{tabular}{lccc}
\hline \hline \multicolumn{1}{c}{ Taxon } & Common name & Number of seeds & \% of seeds caught \\
\hline Rubus spp. & Blackberry species and salmonberry & 4727 & 42 \\
Alnus rubra & Red alder & 2060 & 18 \\
Tellima grandiflora & Fringecup & 525 & 5 \\
Carex leptopoda & Slender-foot sedge & 500 & 4 \\
Betula pendula & European birch & 336 & 3 \\
Acer spp. & Maples & 376 & 3 \\
Urtica dioica & Stinging nettle & 206 & 2 \\
Solanum dulcamara & Bittersweet nightshade & 173 & 2 \\
Poaceae & Grasses & 172 & 2 \\
Unknown taxa & n/a & 153 & 1 \\
Lapsana communis & Nipplewort & 151 & 1 \\
Scirpus microcarpus & Small-fruited bulrush & 150 & 1 \\
Cardamine oligosperma/hirsuta & Little western bittercress/hairy bittercress & 145 & 1 \\
Physocarpus capitatus & Pacific ninebark & 114 & 1 \\
\hline
\end{tabular}

Note: Thirteen taxa made up $98 \%$ of seeds caught across the study, with unknown seeds accounting for an additional $1 \%$. 


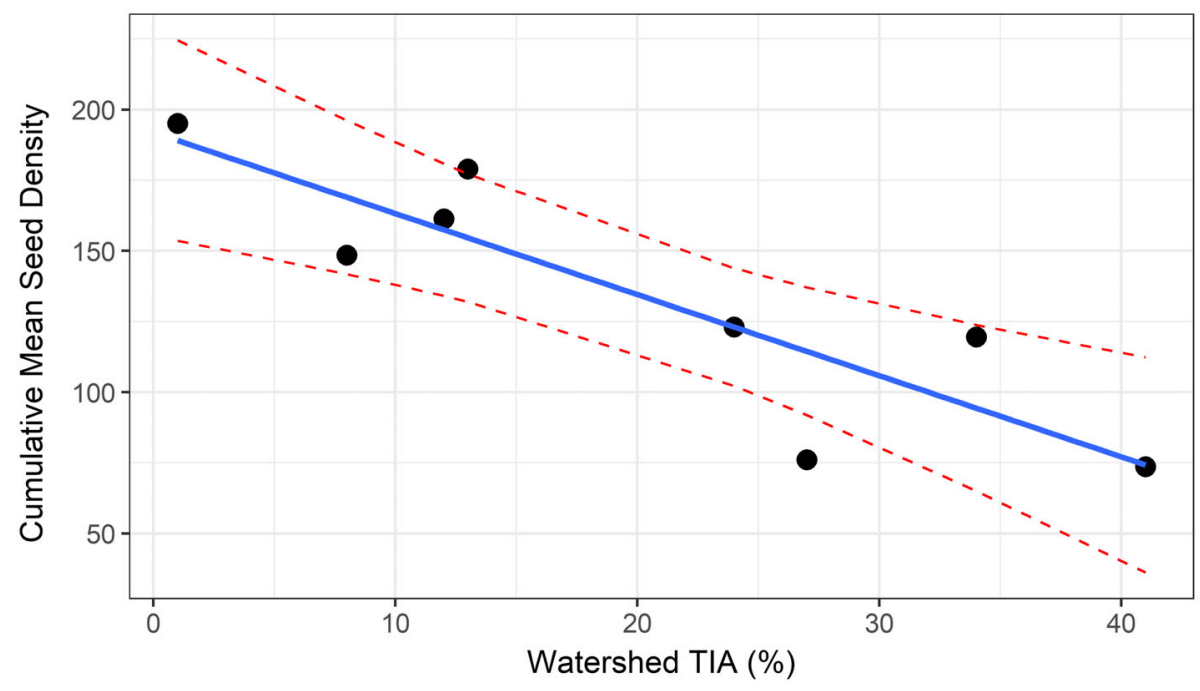

Fig. 2. Cumulative seed density in turf traps across the TIA gradient. $y=-2.87 x+191.95$; adjusted $R^{2}=0.74$; $P<0.01$. Dashed lines indicate the $95 \%$ confidence interval. Across all four collection periods, there was a significant decrease in cumulative mean number of seeds deposited as TIA increased. TIA = total impervious surface area. Mean seed density for each site was calculated as the sum of the mean number of seeds/trap $(n=12)$ in each collection period.

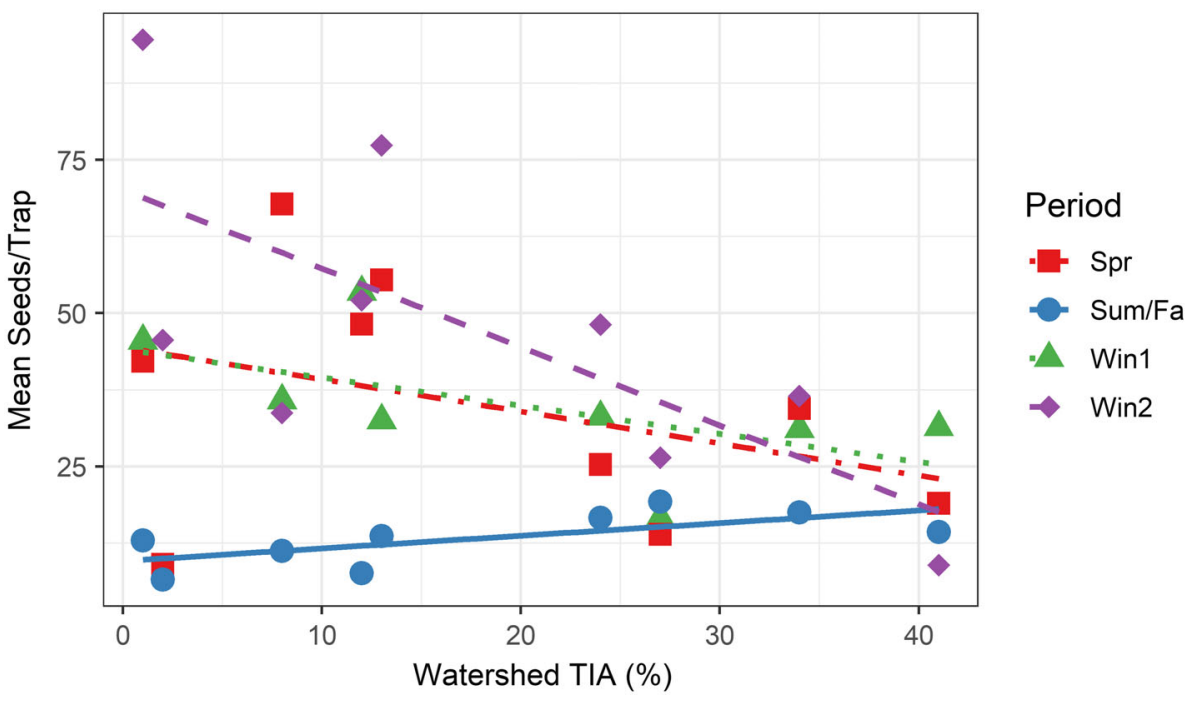

Fig. 3. Mean seed density in turf traps in four collection periods across the TIA gradient. For Sum/Fa and Win2, there was a significant change in mean seed density as TIA increased. Sum/Fa: $y=0.21 x+9.57$; adjusted $R^{2}=0.39 ; P<0.05$. Win2: $y=-1.28 x+70.11$; adjusted $R^{2}=0.42 ; P<0.05$. Sum/Fa was the only collection period when seed density increased with TIA. In Win1 and Spr, the total number of seeds appears to decrease as in Win2, but the relationship between TIA and mean seed density was not statistically significant for these periods $(P>0.05)$. Abbreviations are TIA, total impervious surface area; Win1, December 2014-mid-March 2015; Spr, mid-March-July 2015; Sum/Fa, July-November 2015; Win2, November 2015-March 2016. 
relationships between TIA and total Rubus spp. deposition.

Across the entire study, there was a significant negative relationship between TIA and density of All seeds with no dispersal appendage $\left(y=-1.97 x+120.69 ; \quad\right.$ adjusted $\quad R^{2}=0.49$; $P<0.05)$. The No Appendage class contained Rubus spp., and the relationship was not significant when Rubus spp. was removed from analysis. However, the relationship between TIA and cumulative Rubus spp. density over the entire study was also not statistically significant $(0.05<P<0.1)$, indicating that Rubus spp. alone cannot entirely account for the significant relationship between TIA and density of seeds lacking an appendage. There was no significant relationship between TIA and density of All seeds with a dispersal appendage, or between TIA and density of New seeds with or without an appendage.

There was a significant negative relationship between TIA and density of New native seeds in Win2 $\quad\left(y=-0.11 x+5.46 ;\right.$ adjusted $R^{2}=0.55$; $P<0.05)$. There were no significant relationships between TIA and native seed deposition for other collection periods or cumulatively across the study. There was a significant, positive relationship between TIA and New non-native seed density during Win 1 and Spr (Win1: $y=0.12 x+0.66$; adjusted $R^{2}=0.79 ; \quad P<0.01 ; \quad y=0.10 x+0.12$; adjusted $R^{2}=0.56 ; P<0.05$; Fig. 4 ).

\section{Land cover and seed deposition patterns}

No landscape variables were significantly associated with the ordination of sites when All seed data were used in NMDS. When New seed data were used, five landscape variables were significantly associated with the ordination $(P<0.05)$ : medium-density development and all development within a $250-\mathrm{m}$ cone, medium-density development and all development within a 500-m cone, and medium-density development within the entire watershed. These landscape variables were highly correlated with each other (correlation coefficient 0.79 and higher); all development within a 500-m cone had the highest correlation with other variables and was selected for further analysis with seed deposition data.

There was a significant, positive relationship between all development within a 500-m cone and cumulative density of New non-native seeds

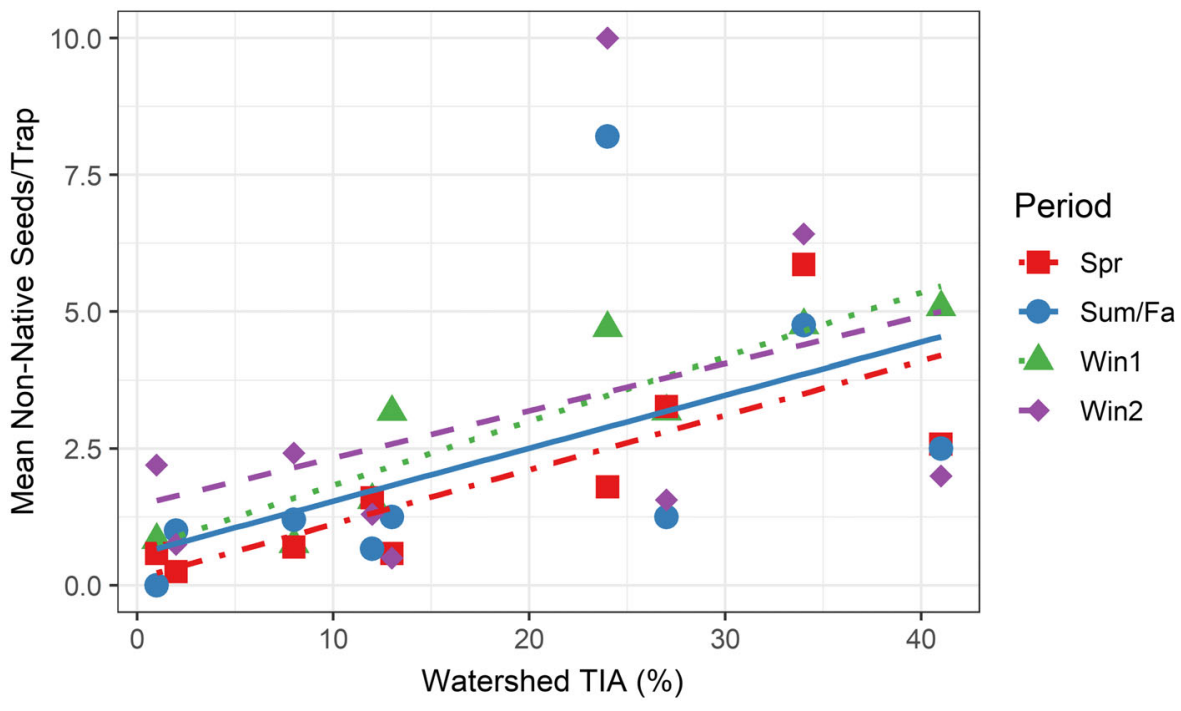

Fig. 4. New non-native seeds in turf traps in four collection periods across the TIA gradient. During Win1 and Spr, there was a significant increase in density of non-native seeds in turf traps as TIA increased. Win1: $y=0.12 x+0.66 ;$ adjusted $R^{2}=0.79 ; P<0.01$. Spr: $y=0.1 x+0.12 ;$ adjusted $R^{2}=0.62 ; P<0.05$. TIA $=$ total impervious surface area. New seeds were those from taxa found in turf traps but not in the standing vegetation in the $1 \mathrm{~m}^{2}$ surrounding the turf trap (herbs and shrubs) or encountered along vegetation transects (trees). Win1, December 2014-mid-March 2015; Spr, mid-March-July 2015; Sum/Fa, July-November 2015; Win2, November 2015-March 2016. 
in turf traps $(y=16.47 x+4.23$; adjusted $\left.R^{2}=0.47 ; P<0.05\right)$. There was also a significant, negative relationship between all development within a 500-m cone and ln-transformed density of New shade-tolerant taxa across the entire study period ( $P<0.05$; Fig. 5$)$, and during Win2 $\left(y=-1.3 x+2.6\right.$; adjusted $\left.R^{2}=0.57 ; P<0.05\right)$.

\section{DISCUSSION}

Our results demonstrate that stream hydrology changed with watershed TIA, consistent with findings from other studies (Morse et al. 2003, Chadwick et al. 2006). In addition, other landscape factors measured at finer scales contributed to stream hydrology responses. For example, although the flashiest stream did not have the highest watershed TIA, it did have the highest development cover within a $250-\mathrm{m}$ cone. This result is consistent with the finding that directly connected impervious surface area surrounding a site is a better predictor of urban stream hydrology than total impervious surface area (Lee and Heaney 2003).

We found strong support for our first hypothesis that seed deposition by water would decrease as watershed urbanization increased. Though the relationship between TIA and seed density varied by collection period, over the entire study there was a strong, negative relationship between watershed TIA and cumulative mean seed density. While seed density did increase with TIA in the summer (Sum/Fa), this was the collection period with lowest stream water levels (Appendix S2: Fig. S2) and lowest overall seed deposition. The winter periods, Win1 and Win2, contributed the most to overall seed deposition across the study and had the highest rainfall and water levels. The observed decrease in seed deposition with increasing TIA during these periods (particularly Win2) suggests that impacts of urbanization on riparian seed deposition are most pronounced during periods of high rainfall.

We found limited support for our second hypothesis that in the most urbanized watersheds, seeds deposited by water would be predominantly from species with traits favoring dispersal in general and dispersal by water in particular. The negative relationship between TIA and density of seeds with no dispersal appendage suggests that such an appendage

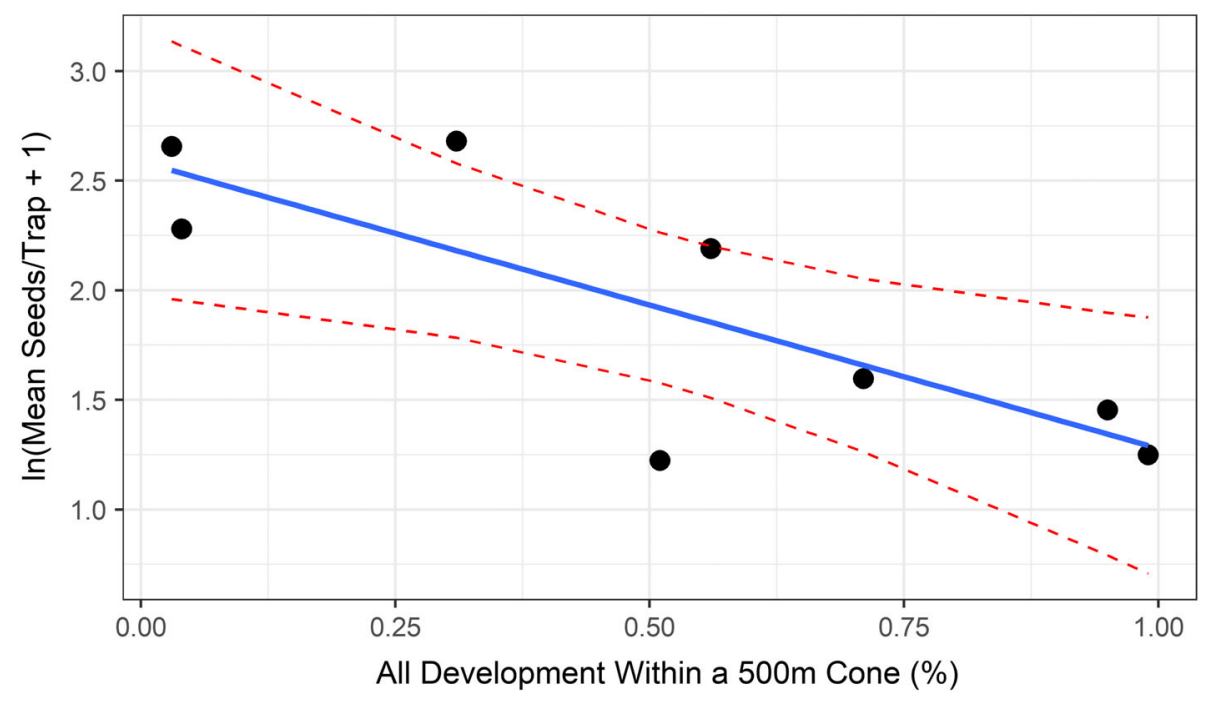

Fig. 5. Cumulative mean density of New shade-tolerant taxa in turf traps along a gradient of development within a 500-m upstream cone, on a natural log scale. Across the entire study, density of New shade-tolerant taxa decreased in turf traps as development within 500 m increased. $y=-1.3 x+2.6$; adjusted $R^{2}=0.57 ; P<0.05$. Dashed lines indicate 95\% confidence interval. All development was determined by summing the cover of the four National Land Cover Database development types within a 500-m upstream cone from each riparian site. New seeds were those from taxa found in turf traps but not in the standing vegetation in the $1 \mathrm{~m}^{2}$ surrounding the turf trap (herbs and shrubs) or encountered along vegetation transects (trees). 
could be assisted with deposition, though this pattern did not hold when potentially new taxa were analyzed. We found little evidence that dispersal by hydrochory of taxa with different seed sizes, mature heights, wetland indicator status, or seed production rates is differentially affected by watershed development.

Several of our findings are suggestive of the role of increased stream bank scour in highly urbanized watersheds. Due to the negative relationship between TIA and total seeds deposited for All seeds, but not for New seeds, we suggest that during winter high-flow events, additional seeds in low TIA sites were coming from local sources and not traveling long distances. For the most part, however, these seeds were not dropped directly from parent plants, as they were deposited in the largest numbers during Win1, Spr, and Win2, largely outside of the fruiting season for most species. While the highest deposition of Rubus spp. seeds in turf traps occurred in the winter periods, Win1 and Win2, this finding contrasted with deposition patterns in traps on the same sites collecting seeds deposited by wind and gravity, in which the highest densities were found during the summer (von Behren and Yeakley, unpublished data). The absence of a significant relationship between Rubus seed density and Rubus in the standing vegetation further demonstrates that the high density of collected Rubus seeds in Win1 and Win2 was not dropped directly from parent plants. Rather, the additional All seeds in low TIA sites were likely present on the ground near turf traps, having been initially deposited the previous summer and autumn. During large winter storms, these seeds were likely remobilized by stream overbank flows and deposited in nearby turf traps when water receded, similar to dynamics observed by Gurnell et al. (2008). With higher, scouring peak flows in the high TIA sites, seeds near turf traps may have been picked up by overbank flows, with many carried away from by the stream instead of being immediately deposited in turf traps, as they were in the low TIA sites. In Sum $/ \mathrm{Fa}$, a period with lower streamflow and less opportunity for scour, All seed deposition did not decrease with TIA as it did in the other seasons. High, scouring winter peak flows in the highest TIA sites could also explain observed relationships between TIA and taxa with no dispersal appendage. With higher peak flows picking up local seeds in high TIA sites, lack of a dispersal appendage could inhibit immediate deposition more than it does in low TIA sites where peak flows are not as high.

Our findings demonstrate that urban stream syndrome affects riparian seed dispersal, but other urbanization pressures play an important role as well. The reduction in All native seed density as TIA increased, as well as the increase in New non-native seeds, reflects the prominence of native and non-native species in likely source pools of the study watersheds. Other studies have shown an increase in non-native propagule pressure with urbanization (Roy et al. 1999), as well as a decrease in native seed source pools as a direct result of loss of native riparian vegetation (Ehrlen and Erikkson 2000, Mendoza et al. 2009). Likewise, decreased deposition of shade-tolerant species with increasing development within a $500-\mathrm{m}$ cone reflects the composition of nearby source pools. In a study of 30 small-stream riparian forests in the Portland metro area, cover by non-native species was significantly higher in sites surrounded by high amounts of urban development than in sites surrounded by forest (von Behren et al. 2013). The finding that deposition patterns reflect surrounding source pools is consistent with studies that linked a decrease in prevalence of shade-tolerant species to increasing forest fragmentation and loss of connectivity (Metzger 2000, Burton et al. 2009).

This study demonstrates that urbanization impacts patterns of seed dispersal by hydrochory in urban riparian areas. While the symptoms of urban stream syndrome are clearly contributing factors, our findings demonstrate that other urban drivers that alter propagule pressure also play a role. Specifically, the combination of increased stream bank scour and alteration of seed source pools may inhibit the regeneration capacities of some riparian plant species and markedly alter the plant species compositions of riparian forest communities.

\section{ACKNOWLEDGMENTS}

We thank Sarah Eppley, Martin Lafrenz, Joe Maser, and Angela Strecker for their comments on an earlier version of this work. We also thank Troy McKinley, Kristen Meyer, Kristen Purdy, and Neil Robinson, for 
assistance with fieldwork and laboratory work. We are also grateful for the helpful comments from two anonymous reviewers. This study was funded by the GK-12 Cascades to Coast Doctoral Fellowship (NSF Grant Number 0948041) and grants from the American Reinvestment and Recovery Act and US Forest Service Pacific Northwest Research Station, and the Native Plant Society of Oregon.

\section{Literature Cited}

Alados, C. L., T. Navarro, B. Komac, V. Pascual, and M. Rietkerk. 2010. Dispersal abilities and spatial patterns in fragmented landscapes. Biological Journal of the Linnean Society 100:935-947.

Bates, D., M. Maechler, B. Bolker, and S. Walker. 2015. Fitting linear mixed-effects models using lme4. Journal of Statistical Software 67:1-48.

Boedeltje, G., J. P. Bakker, R. M. Bekker, J. M. Van Groenendael, and M. Soesbergen. 2003. Plant dispersal in a lowland stream in relation to occurrence and three specific life-history traits of the species in the species pool. Journal of Ecology 91:855-866.

Bolker, B. M., M. E. Brooks, C. J. Clark, S. W. Geange, J. R. Poulsen, M. H. H. Stevens, and J. S. White. 2008. Generalized linear mixed models: a practical guide for ecology and evolution. Trends in Ecology and Evolution 24:127-135.

Bonner, F. T., R. P. Karrfalt, and R. G. Nisley, editors. 2008. The woody plant seed manual. USDA forest service agriculture handbook 727. U.S. Department of Agriculture, Forest Service, Washington, D.C., USA.

Booth, D. B., D. Hartley, and R. Jackson. 2002. Forest cover, impervious-surface area, and the mitigation of stormwater impacts. Journal of the American Water Resources Association 38:835-845.

Brown, D. 1992. Estimating the composition of a forest seed bank: a comparison of seed extraction and seedling emergence methods. Canadian Journal of Botany 70:1603-1612.

Burton, M. L., L. J. Samuelson, and M. D. Mackenzie. 2009. Riparian woody plant traits across an urbanrural land use gradient and implications for watershed function with urbanization. Landscape and Urban Planning 90:42-55.

Cappers, R. T. J., R. M. Bekker, and J. E. A. Jans. 2006. Digital Seed Atlas of the Netherlands. Groningen Archaeological Studies 4. Barkhuis Publishing, Eelde, The Netherlands. www.plantatlas.eu

Chadwick, M. A., D. R. Dobberfuhl, A. C. Benke, A. D. Huryn, K. Suberkropp, and J. E. Thiele. 2006. Urbanization affects stream ecosystem function by altering hydrology, chemistry, and biotic richness. Ecological Applications 16:1796-1807.
Chambert, S., and C. S. James. 2009. Sorting of seeds by hydrochory. River Research and Applications 25:48-61.

Christy, J. A., A. Kimpo, V. Marttala, P. K. Gaddis, and N. L. Christy. 2009. Urbanizing flora of Portland, Oregon, 1806-2008. Native Plant Society of Oregon Occasional Paper 3:1-319.

Cunnings, A., E. Johnson, and Y. Martin. 2015. Fluvial seed dispersal of riparian trees: transport and depositional processes. Earth Surface Processes and Landforms 41:615-625.

Ehrlen, J., and O. Erikkson. 2000. Dispersal limitation and patch occupancy in forest herbs. Ecology 81:1667-1674.

Engstrom, J., C. Nilsson, and R. Jansson. 2009. Effects of stream restoration on dispersal of plant propagules. Journal of Applied Ecology 46:397405.

ESRI. 2014. ArcGIS Desktop version 10.4. ESRI, Redlands, California, USA.

Fraaije, R. G. A., S. Moinier, I. van Gogh, R. Timmers, J. J. van Deelen, J. T. A. Verhoeven, and M. B. Soons. 2017. Spatial patterns of water-dispersed seed deposition along stream riparian gradients. PLOS ONE 12:e0185247.

Fraaije, R. G. A., C. J. F. ter Braak, B. Verduyen, J. T. A. Verhoeven, and M. B. Soons. 2015. Dispersal versus environmental filtering in a dynamic system: drivers of vegetation patterns and diversity along stream riparian gradients. Journal of Ecology 103:1634-1646.

Goodson, J. M., A. M. Gurnell, P. G. Angold, and I. P. Morrissey. 2003. Evidence for hydrochory and the deposition of viable seeds within winter flow-deposited sediments: the River Dove, Derbyshire, UK. River Research and Applications 19:317-334.

Groffman, P. M., D. J. Bain, L. E. Band, K. T. Belt, G. S. Brush, J. M. Grove, R. V. Pouyat, I. C. Yesilonis, and W. C. Zipperer. 2003. Down by the riverside: urban riparian ecology. Frontiers in Ecology and the Environment 6:315-321.

Gurnell, A. M., K. Thompson, J. Goodson, and H. Moggridge. 2008. Propagule deposition along river margins: linking hydrology and ecology. Journal of Ecology 96:553-565.

Hampe, A. 2004. Extensive hydrochory uncouples spatiotemporal patterns of seedfall and seedling recruitment in a 'bird-dispersed' riparian tree. Journal of Ecology 92:797-807.

Hérault, B., and O. Honnay. 2005. The relative importance of local, regional and historical factors determining the distribution of plants in fragmented riverine forests: an emergent group approach. Journal of Biogeography 12:2069-2081. 
Hitchcock, C. L., and A. Cronquist. 1973. Flora of the Pacific Northwest. University of Washington Press, Seattle, Washington, USA.

Homer, C. G., J. A. Dewitz, L. Yang, S. Jin, P. Danielson, G. Xian, J. Coulston, N. D. Herold, J. D. Whickham, and K. Megown. 2015. Completion of the 2011 National Land Cover Database for the coterminous United States - Representing a decade of land cover change information. Photogrammetric Engineering and Remote Sensing 81:345-354.

Honnay, O., W. Verheyen, J. Butaye, H. Jacquemyn, B. Bossuyt, and M. Hermy. 2002. Possible effects of habitat fragmentation and climate change on the range of forest plant species. Ecological Letters 5:525-530.

Kenkel, N. C., and L. Orlóci. 1986. Applying metric and nonmetric multidimensional scaling to ecological studies: some new results. Ecology 67:919-928.

Lee, J. G., and J. P. Heaney. 2003. Estimation of urban imperviousness and its impacts on storm water systems. Journal of Water Resources Planning and Management 129:419-426.

Malone, C. R. 1967. A rapid method for enumeration of viable seeds in soil. Weeds 15:381-382.

May, C. W., and R. R. Horner. 2000. The cumulative impacts of watershed urbanization on stream-riparian ecosystems. Pages 281-286 in P. J. Wigington and R. L. Beschta, editors. Proceedings of the American Water Resources Association International Conference on riparian ecology and management in multi-land use watersheds. American Water Resources Association, Portland, Oregon, USA.

McEuen, A. B., and L. M. Curran. 2004. Seed dispersal and recruitment limitation across spatial scales in temperate forest fragments. Ecology 85:507-518.

Mendoza, I., L. Gómez-Aparicio, R. Zamora, and L. Matías. 2009. Recruitment limitation of forest communities in a degraded Mediterranean landscape. Journal of Vegetation Science 20:367-376.

Merritt, D. M., C. Nillson, and R. Jansson. 2010. Consequences of propagule dispersal and river fragmentation for riparian plant community diversity and turnover. Ecological Monographs 80:609-626.

Merritt, D. M., and E. E. Wohl. 2002. Processes governing hydrochory along rivers: hydraulics, hydrology, and dispersal phenology. Ecological Applications 12:1071-1087.

Metzger, J. P. 2000. Tree functional group richness and landscape structure in a Brazilian tropical fragmented landscape. Ecological Applications 10:1147-1161.

Meyers, S. C., T. Jaster, K. E. Mitchell, and L. K. Hardison. 2015. Flora of Oregon. Volume 1: pteridophytes, Gymnosperms, and Monocots. Botanical
Research Institute of Texas, Fort Worth, Texas, USA.

Minchin, P. R. 1987. An evaluation of the relative robustness of techniques for ecological ordination. Vegetatio 69:89-107.

Moggridge, H. L., and A. M. Gurnell. 2010. Hydrological controls on the transport and deposition of plant propagules within riparian zones. River Research and Applications 26:512-517.

Moggridge, H. L., A. M. Gurnell, and J. O. Mountford. 2009. Propagule input, transport and deposition in riparian environments: the importance of connectivity for diversity. Journal of Vegetation Science 20:465-474.

Morse, C. C., A. D. Huryn, and C. Cronan. 2003. Impervious surface area as a predictor of the effects of urbanization on stream insect communities in Maine, USA. Environmental Monitoring and Assessment 89:95-127.

Nilsson, C., R. L. Brown, R. Jansson, and D. M. Merritt. 2010. The role of hydrochory in structuring riparian and wetland vegetation. Biological Reviews 85:837-858.

Oksanen, J., F. G. Blanchet, R. Kindt, P. Legendre, P. R. Minchin, R. B. O'Hara, G. L. Simpson, P. Solymos, M. H. H. Stevens, and H. Wagner. 2012. Vegan: community Ecology Package. R Package Version 2.0-5. http://cran.r-project.org/package=vegan

R Development Core Team. 2017. R: a language and environment for statistical computing. R Foundation for Statistical Computing, Vienna, Austria.

Randhir, T., and P. Ekness. 2009. Urbanization effects on watershed habitat potential: a multivariate assessment of thresholds and interactions. Ecohydrology 2:88-101.

Roy, D. B., M. O. Hill, and P. Rothery. 1999. Effects of urban land cover on the local species pool in Britain. Ecography 22:507-515.

Samuel, I., and I. Kowarik. 2013. Propagule morphology and river characteristics shape secondary water dispersal in tree species. Plant Ecology 214:1257-1272.

Sonoda, K., J. A. Yeakley, and C. E. Walker. 2001. Nearstream landuse effects on streamwater nutrient distribution in an urbanizing watershed. Journal of the American Water Resources Association 37:1517-1532.

Vogt, K., L. Rasran, and K. Jensen. 2004. Water-borne seed transport and seed deposition during flooding in a small river-valley in Northern Germany. Flora 199:377-388.

von Behren, C., A. Dietrich, and J. A. Yeakley. 2013. Riparian vegetation assemblages and associated landscape factors across an urbanizing metropolitan area. Ecoscience 20:373-382. 
Walsh, C. J., A. H. Roy, J. W. Feminella, P. D. Cottingham, P. M. Groffman, and P. M. Raymond II. 2005. The urban stream syndrome: current knowledge and the search for a cure. Journal of the North American Benthological Society 24:706-723.

Wenger, S. J., C. H. Luce, A. F. Hamlet, D. J. Isaak, and H. M. Neville. 2010. Macroscale hydrologic modeling of ecologically relevant flow metrics. Water Resources Research 46:W09513.

Willson, M. F., and A. Travaset. 2000. The ecology of seed dispersal. Pages 85-110 in M. Fenner, editor. Seeds, the ecology of regeneration in plant communities. CAB International, Wallingford, UK.
Wilson, B. L., R. Brainerd, D. Lytjen, B. Newhouse, and N. Otting. 2014. The field guide to the sedges of the Pacific Northwest. Second edition. Oregon State University Press, Corvallis, Oregon, USA.

Wolters, M., J. Geertsema, E. R. Chang, R. M. Veeneklaas, P. D. Carey, and J. P. Bakker. 2004. Astroturf seed traps for studying hydrochory. Functional Ecology 18:141-147.

Yeakley, J. A. 2014. Urban hydrology in the Pacific Northwest. Pages 59-74 in J. A. Yeakley, K. G. Maas-Habner, and R. M. Hughes, editors. Wild salmonids in the urbanizing Pacific Northwest. Springer, New York, New York, USA.

\section{SUPPORTING INFORMATION}

Additional Supporting Information may be found online at: http://onlinelibrary.wiley.com/doi/10.1002/ecs2. 3049/full 